Jpn. J. Oral Biol., $25: 289-298,1983$.

\title{
アジアゾウ（Elephas maximus）の牙のエナメル質
}

\section{についての系統発生学的考察}

\author{
小沢幸重立石 みどり \\ 日本大学松戸歯学部第 2 解剖学教室 (主任 : 平井五郎教授) \\ [受付 : 昭和57年12月20日]
}

\section{On the structure of the enamel in the Indian elephant Tusk from the phylogeny of Proboscidea.}

\author{
Yukishige Kozawa and Midori Tateishi. \\ Department of Oral Histology, Nihon University School of Dentistry at Matsudo, \\ (Chief. Prof. Goro Hirai)
}

2-870-1, Sakae-cho Nishi, Matsudo, Chiba 271

[Accepted for publication : December 20, 1982]

Keywords : enamel/enamel prism/prism pattern/Proboscidea/phylogeny

\begin{abstract}
Materials are a tusk of a young Indian elephant (Elephas maximus LINNÉ) without any abrasion on its surface, and molars of Moeritherium and Palaeomastodon. The inside and outside of the tip of the tusk are covered with a thin enamel layer and a thin cemenuum layer, respectively.

On the tusk, a histological examination by light- and scanning electron-microscopy has revealed some different characteristics from those of the molar teeth. Hunter-Schreger's bands are developed in the inner two-third of the enamel layer, though the outer one-third is a prismless enamel layer with distinct Retzius lines. Schreger's bands of the enamel form more regular rows in the tusk than in the molar teeth. Each band is some $30 \mu \mathrm{m}$ wide and is composed of $10-15$ enamel prisms in a parazone. The enamel prism is $4-5 \mu \mathrm{m}$ in diameter and shows a key-hole pattern similar to that of human teeth. Ginkgo leaf patterns characteristic of the Elepas molar enamel can not be observed in the tusk enamel. Processes of dentinal tube of several $\mu \mathrm{m}$ in length are there in the enamel layer just adjacent to the dentino-enamel junction, though no large enamel spindles are observed.

The enamel of Moeritherium and Palaeomastodon has the key-hole pattern of enamel prism and well developed Hunter-Schreger's band same as the Mastdon.

The histological features of the Indian elephant tusk enanel are similfar to those of the molar enamel of Moeritherium. Palaeomastodon, Mastdon and Stegodon, which is supposed to be an ancestral genus of Elephas.
\end{abstract}

緒言

現在生きている長鼻類（アフリカゾウ：Loxodonta africana とアジアゾウ : Elephas maximus) は, 比較解剖学的に非常に特異的な歯を持 つ。牙は巨大であり, アフリカゾウでは $100 \mathrm{~kg}$ を こすこともある。且歯は, 巨大でかつ複雑な歯冠 形態を示し, 咬頭に相当する咬板がときに 20 数枚 を越えることもあり, 複雑に発達した被壁エナメ ル質の表面には歯冠セメント質が厚く発達する。

千葉県松戸市栄町西 2-870-1 (兵271)
系統発生学的な研究では, これら長鼻 類の歯 がごく通常の形態・大きさを示す Moeritherium の歯から進化してきたことが明らかである Moeritherium は，ブタ程度の大きさの動物であ り, ごく普通の形態の側切歯, $2 \backsim 3$ 咬頭をもつ 丘状ないしは鈍頭歯型の且歯を持つ。

長鼻類の歷史におけるこのような歯の形態的変 化をもたらす要因は，いまだ不明のままであり。 この解明の一端をになうべき歯の組織学的研究も 多くない, ${ }^{8,11-13)}$ 。

哺乳動物の歯の組織のうちで最も変化に富むひ 
とつであるエナメル質は，この問題に対する有効 な材料であると考えられる。なぜなら Elephas, の牙（側切歯であるが，一般的な牙という名称を 用いる）のエナメル質は、その先端にほんの少量 形成されるだけであるが, アジアゾウの牙のエナ メル質組織と臼歯のそれは異なる点が認られ れが系統発生的な原因を持つと推定されるからで ある。

そこで，本報告では報告の少ないアジアゾウの 牙のエナメル質を記載し，これと臼歯のエナメル 質, さらに, Moeritherium, Palaeomastodon と いう約 $5 \backsim 6000$ 万年前の最古の長鼻類のエナメル 質との比較を行い, 歯の組織と形態的変化の関連 性について検討したので報告する。

\section{方法}

試料は以下のとおりである。 Moeritherium (Moeritherium lyonsi, Egypt Fayum, 始新世) の第 3 大臼歯, Palaeomastodon (Palaeomastodon parvus, Egypt Fayum, 初期漸新世) の第 2 大臼歯, 直径 $15 \mathrm{~mm}$ のアジアゾウ (Elephas maximus) の牙のエナメル質（大きさから推定 して, 乳歯である)。各試料は, おもに綐断面に おいて光学顕微鏡用の研磨標本を作製した。

電顕用の試料は, エメリ一粉（No. 1500, および No. 3000) であらかじめ研磨し，ダイヤモンドペ ースト(Struers社) で仕上の研磨をした。仕上げ では, 金属顕微鏡で傷が認られないことを確認し た。さらに試料を超音波洗浄して研磨材を落し た。

つぎに $0.5 \%$ 塩酸にて約 $10 \backsim 30$ 秒間腐蝕し，ア ルコール脱水後, 腐蝕面にカーボン・ゴールドの 二重蒸着をほどこし, 日立 X-560型走査電顕を用 いて観察した。

\section{結果}

$1:$ アジアゾウの牙のエナメル質

エナメル質は厚さが最大で約 $0.7 \mathrm{~mm}$ 程あり， 牙の周囲数ケ所に, 不連続的に認められる。エナ メル質の表面は, 厚さ $0.2 \sim 0.5 \mathrm{~mm}$ の歯冠セメン ト質がおおう（Fig. 1) が，歯冠セメント質がな
くエナメル質が露出している部位もある。また, エナメル質が存在しない部位では，象牙質の表面 を直接セメント質がおおう。

シュレーゲルの条紋は，エナメル象牙境にたい して $50^{\circ} \backsim 60^{\circ}$ の角度で牙の先端方向に傾いてお り, エナメル質全層の $2 / 3 \backsim 3 / 4$ の領域に認められ る(Fig. 1)。象牙質に近い部位では, シュレーゲ ルの条紋の走行が乱れており, 綐断帯と横断帯の 区別が明瞭でない。

一般に, 各帯とも約10ー15本のエナメル小柱に よって構成されている。エナメル小柱の走行には 2 つの型が認められる。第一はエナメル象牙境か らまず歯根方向に走行し, 反転屈曲して牙の先端 へ向いエナメル表面に達するものである。第二 は，まずエナメル象牙境から牙の先端方向へむか い, 途中で反転して歯根方向へ走行するが，再度 反転して牙の先端へ向って走行し、エナメル質表 面に達するものである。前者はおもに縦断帯に認 られ, 後者は横断帯に観察される。

エナメル象牙境には，ごく少数の単純突起様構 造が認められる(Fig. 1，2)。この突起は，象牙細 管と連続していて, 数 $\mu \mathrm{m}$ エナメル質へ侵入して いる。

エナメル質の表面は, ゆるやかなカーブをしめ して歯冠セメント質と接し，臼歯のエナメル質表 面に認られるような著しい凹凸8) は観察されない (Fig. 1)。

電顕的に観察すると, エナメル質の各層は組織 学的特徵が多少異なる。エナメル象牙境に接する 幅約 $10 \mu \mathrm{m}$ の層では, 2 つの型のエナメル小柱の 断面が観察される。ひとつは，エナメル小柱の周 囲に, 酸腐蝕によるアーチ型の溝が形成されるも のであり, 径約 $4 \mu \mathrm{m}$ である (Fig. 3 )。小柱間エ ナメル質は，厚くエナメル小柱を囲む。

他の型は、エナメル小柱の断面がヒトの鍵穴形 に類似するものであり，小柱間エナメル質がエナ メル小柱の尾となる (Fig. 3，4)。酸腐蝕をうけ たエナメル小柱の周囲の溝はひじょうに狭く、溝 の両岸, つまりエナメル小柱の周辺の結晶は, 酸 に抵抗性を示し堤状に残存する。鍵穴形のエナメ

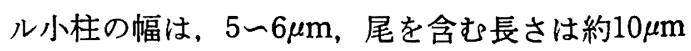
であるが，エナメル象牙境に近いものほど小型で 
ある。

後者の型のエナメル小柱は, エナメル質全層中 の象牙質側の約 $1 / 3$ の領域において, 最も多く観 察される。しかし, アジアゾウの臼歯のエナメル 質に特徴的に出現するイチョウの葉形のエナメル 小柱 (Mummery, ${ }^{12)}$ は, エナメル小柱の断面の 集合状態からシダの葉の形と指摘したが, 1 本 1 本の断面はイチョウの葉の形の方が理解しやすい のでこの用語を使用する Fig. 5 ) は、ほとんど 観察されない。

偏光顕微鏡的には，エナメル象牙境に接する一 層のエナメル質の結晶配列が同じ方向に配列して いるために, この部分に無小柱エナメル質の存在 を認めることができる。しかし，電顕的には，明 瞭な無小柱エナメル質は, エナメル質深層にあま り認められない(Fig. 6)。

しかし、アーチ形の断面をしめすェナメル小柱 の結晶配列は, 小柱間エナメル質の結晶とほぼ同 ビ方向である。つまりエナメル象牙境にほぼ垂直 な配列をしており、この層が偏光顕微鏡的な無小 柱エナメル質と一致するものと考えられる。

シュレーゲルの条紋が認められる層のうちエナ メル質表面側約 $1 / 2$ の層では, エナメル小柱周囲 の酸腐蝕による溝が, エナメル質表面に近づくに したがい徐々に広くなる (Fig. 7)。これととも に, エナメル小柱の断面も不明確となり, 全体的 になめらかに観察され, 結晶配列が判別できにく くなる (Fig. 7, 8)。このようなエナメル小柱周 辺の広い溝の中には, 粘調性の有機質のような線 維状物質が観察される。

シュレーゲルの条紋が存在しないエナメル質の 表面側の層は, 小柱間エナメル質が広く、わずか な数の円形の断面をなすエナメル小柱が観察され る。エナメル小柱の直径は, エナメル質表面に近

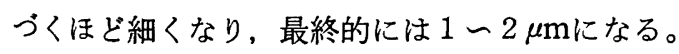
この領域は, 電顕的にすべての結晶配列が, エナ メル質の表面にほぼ垂直となり偏光顕微鏡的な所 見と一致し，無小柱エナメル質といえよう。

エナメル質の表面近くになると, 電顕的にレッ チウスの線条が明瞭であるが (Fig. 9，10)，その 間には，さらに狭い約 $5 \mu \mathrm{m}$ 間隔の成長線が観察 される。いっぽう象牙質に近い領域においては,
約 $3 \mu \mathrm{m}$ 間隔の横紋が認められ, 表層エナメル質 と深層エナメル質の形成速度の差が暗示される。

2 : Moeritherium と Palaeomastodon の臼 歯エナメル質

Moeritherium のエナメル質 : 最大で約 $1 \mathrm{~mm}$ の厚さがあり歯冠セメント質は認められない。シ ニレーゲルの条紋は, 規則的に配列し、エナメル 象牙境より約60度の角度を持って走行する。しか し、エナメル小柱の走行が比較的簡単であるた め、シュレーゲルの条紋の発達は良いとはいえな い(Fig. 11)。エナメル小柱は, 規則的な配列を示 し断面は $5 \backsim 6 \mu \mathrm{m}$ の幅の鍵穴形である(Fig. 12)。 エナメル象牙境付近には, 若干のエナメル紡錘が 認らるれ。

Palaeomastodon のエナメル質 : Moeritherium よりやや厚く最高で $1.5 \mathrm{~mm}$ ほどの厚さを示 し, 歯冠セメント質は認められない。シュレーゲ ルの条紋は, 非常に規則的に横断帯と縦断帯が 認られ，エナメル象牙境より約 70 度の角度をも って，エナメル質表面にむかって走行する (Fig. 13)。両帯とも15 20本のエナメル小柱よりなり, エナメル質表面近くですべてのエナメル小柱は平 行になり, 両帯の区別は不明となる。Palaeomastodon のシュレーゲルの条紋は, Moeritherium のそれよりも著しく発達し, 横断帯のエナメル小 柱の走行が非常に複雑である。

エナメル小柱の断面は, 幅 $5 \backsim 6 \mu \mathrm{m}$ の鍵穴形 を主体とする (Fig. 14)。エナメル紡錘の数は少 ない。

\section{考察}

現生長鼻類の先祖は, 約 6500 万年前の Moeritherium であるといわれる。長鼻類の進化過程に ついては、いくつかの学説もあるが6,10,13), 臼歯 の形態変化の点からみるならば, Moeritherium を第一段階とし, 次に白歯が大型化し, 多咬頭化 した Mastodon 段階, 続いて歯冠セメント質の 発達するStegodon 段階を経て, 現生の長冠歯, 皱壁エナメル質となった Elephas 段階へ到達し たとされようア。

これまでの長鼻類の臼歯の組織学的研究は, Elephas の段階のものが多く，多少の相違はある 
が，ヒトの歯の組織と類似するとされている ${ }^{1,3,11,}$ 12,14)。しかし, 各進化段階の臼歯の組織を比較す ると、古い段階ほどヒトと類似するが，新しく進 化した長鼻類では著しい違いがある4)。

筆者は, エナメル小柱の断面の歴史的な変化過 程から，その差が臼歯の巨大化と複雑化をともな った形態変化と関連するものと推定している ${ }^{8)}$ 。 しかし、いづれの報告も、最古の長鼻類である Moeritherium の歯の組織について検討するまで に致っておらず, 進化についての検討は不十分の ままとなっている。

歯の形態について考えるならば，牙は，巨大な 無根歯に進化した点を除けば，臼歯のように複雑 化した形態上の特殊化を示さない。つまり，Moeritherium の単純な形態の上顎の側切歯が, 長 さ約 $2 \mathrm{~m}$, 直径約 $15 \mathrm{~cm}$ もの巨大な牙状を呈し, エナメル質がその先端のみにごく少量極在する無 根歯となったものである。

牙は，ほとんどが象牙質でできており，象牙質 が巨大化したものである。その反面で，エナメル 質が著しく退化縮小したものと考えることができ る。つまり, 進化の過程に扔いて牙は歯冠が原始 型を保ちつつ，歯根が巨大化したとみなすことも できる。これに対して，臼歯は歯根が水平交換に 適応して退化し, 歯冠が解壁歯・長冠歯として巨 大化, 複雑化したものといえよう。すなわち, 歷 史的にみるならば一個体の切歯と臼歯が, 他の動 物より極端にそれぞれ別々の方向へ特殊化したも のである。

本報告に使用した牙のエナメル質は，厚さの点 では約 $0.7 \mathrm{~mm}$ と薄いが、シュレーゲルの条紋が 全層の約 $2 / 3$ まで達しており (Fig. 1，9), 表面に は無小柱エナメル質が認められ, 完成した組織で ある。アジアゾウの乳歯の牙のエナメル質が，そ の周囲に分散して存在することは, Miller ${ }^{11)} に よ$ って，すでに報告されている。この形質は，現生 のカバの切歯や犬歯にも認められるが, 長鼻類の 先祖である Moeritherium の側切歯においても やはり同様であるという(13)。しかし, 他方では, アジアゾウやアフリカゾウの牙のエナメル質は, その先端を帽子状に覆って存在していることが報 告されている ${ }^{5,15)}$ 。
この違いは, 乳歯と永久歯の差異によるものと 考えられるが，牙の交換については代生歯がない という考えもあり，結論づけることはできない。 しかし，ヒトの歯においても，永久歯より乳歯に 原始的な形質が多いことはよく知られており，同 様の現像は，長鼻類においても十分におこりらる であろう。

牙のシュレーゲルの条紋は， 臼歯のエナメル質 のような不規則な配列をしていないが，草食動物 に特有な規則性をも持たない7)。最古の長鼻類の Moeritherium のシュレーゲルの条紋は，比較的 単純であり，また，Palaeomastodon では規則的 で草食動物型とほぼ一致するため,この両者と牙 のそれとは隔たりがある。つまり, 牙のシュレー ゲルの条紋は, 長鼻類の臼歯の進化段階 として は, Elephas の前段階に相当する, Stegodon 段 階ないし Mastodon 段階のシュレーゲルの条紋 に比較的類似しているといえよゔ)。

牙のエナメル質の哚層には, 走查電顕的に明瞭 な無小柱エナメル質が認められなかったが，以下 の緒点により，ほぼ同様な構造が存在すると考え られる。すなわち, エナメル象牙境に接する一層 のエナメル質は, 偏光顕微鏡的に結晶が同一方向 に配列すること, 走查電顕的に臼歯のエナメル質 の深層におけるものと類似したエナメル小柱, お よび小柱間エナメル質の構造を若干ながら認めた ことである。

単純突起は，象牙細管と連続しており，エナメ ル質内へ数 $\mu \mathrm{m}$ まで侵入していたが, ヒトのエナ メル紡鍾様の構造は認められなかった(Fig. 1,2)。 これは臼歯とほぼ同様な特徵といえるが，突起の 数は牙では著しく少くない。

Moeritherium, Palaeoastodon ともにエナメ ル紡鍾は認められるが，その数は少ない。エナメ ル紡錘は, 原始的哺乳動物のエナメル細管に由来 すると考えられ2), その数の少ないこと及び小形 である点に拉いて，歯の進化が進んだことと関連 性があるものと推定できよう。つまり, Moeritherium 段階においてすでにエナメル質の進化 は相当に進んでいたと考られよう。

牙に扔いて, 単純突起の数が少くないことは, エナメル質の退化縮小, および象牙質の巨大化の 
現象とに関連すると推定しえるが，同様の特殊化 をおこなった歯における今後の検討も必要であろ う。

エナメル質の表面側約 $2 / 3$ は, 酸腐蝕でなめら かな面となり，石灰化が低い状態を示している。 これは，牙のエナメル質は一応完成したものと考 えられるが，反面，石灰化が十分高くないことを 示している。エナメル質の退化縮小にともなう， エナメル芽細胞のエナメル質形成能の退化と考え ることもできる。

牙のエナメル小柱の断面は, ほぼヒトのものと 同形同大である。一方臼歯のエナメル質に特有な エナメル小柱の断面は, イチョウの葉形であり牙 のエナメル小柱より大型である ${ }^{12)}$ (Fig. 6 )。田歯 のエナメル質にも鍵穴形のエナメル小柱が認めら れるが、この型はむしろ Moeritherium, Mastodon 段階の臼歯のエナメル質に一般的に存在 し (Fig. 15,16), 長鼻類では古い型のエナメル 小柱と推定される ${ }^{8)}$ 。

このような牙のシュレーゲルの条紋およびエナ メル小柱の形から、牙のエナメル質の組織は、今 回観察した限りにおいて, 臼歯のエナメル質より む原始的な形質を持つと考えられる。しかし，本 報告における試料が限定されており，また牙が乳 歯である可能性もあることから，今後，他の進化 段階にある長鼻類の牙のエナメル質の組織と比較 研究をおこなうことが必要である。

\section{結論}

アジアゾウの牙 (側切歯, 乳歯と推定される)の 先端に極在するエナメル質と， Moeritherium,
Palaeomastodon の臼歯エナメル質とを偏光顕微 鏡および走查電顕を用いて観察した。

牙のエナメル質は約 $0.7 \mathrm{~mm}$ と薄く, その周囲 に分散して存在する。エナメル質全層の約 $2 / 3$ を シュレーゲルの条紋が走行し、これを欠く表層の エナメル質は無小柱エナメル質である。シュレー ゲルの条紋は、臼歯エナメル質では不規則である が，牙においては比較的規則的である。

エナメル小柱の断面は. Moeritherium, Palaeomastodon, 牙ともに, ほぼヒトのものと同形同 大の鍵穴形である。しかも, Elephas の臼歯エナ メル質に特有なイチョウの葉形をしたエナメル小 柱は観察されない。典型的なエナメル紡鍵は認め られず, 長さ数 $\mu \mathrm{m}$ の単純突起がごく少数観察さ れらるのみである。

牙の組織学的特徵の大半は, アジアジウを含む Elephas 段階の先祖型の Moeritherium. Mastodon ないし Stegodon 段階の臼歯の組織とより多 くの類似点があり，これは牙と臼歯の特殊化の違 い，および本報告に用いた牙の試料が乳歯と推定 されるためのものとも考えられる。

今回の観察は牙の組織を多量に観察したもので はないという問題点を持つが, 長鼻類の歯の組織 は比較的歯種, 部位により一定しているため ${ }^{8)}$, 以上のような議論, 推定を行なったものである。

稿を終るにあたり, 御指導, 御援助いただいた, 日本大学平井五郎教授, 日本大学松戸歯学部解剖学 教室の諸氏, 井尻正二博士をはじめとする化石研究 会, 長鼻類団体研究会の諸氏に深謝する次第であ る。

抄録：Elephas maximus (アジアジウ) の牙のエナメル質と，その祖先である Moeritherium, Palaeomastodon の臼歯のエナメル質とを光顕，電顕的に比較した。 アジアジウの牙は，側切歯が変ったものと考えら れており, 先端には歯冠セメント質に被われた薄いエナメル質がある。シュレーゲルの条紋は, エナメル象牙 境から $2 / 3$ まで発達しているが, 表層 $1 / 3$ はレッチウスの線条が顕著に認められる無小柱エナメル質である。シ ユレーゲルの条紋は, 約 $30 \mu \mathrm{m}$ の幅で, 各帯は10 15本のエナメル小柱で構成され, 牙で認められるものは, Elephasmaximus の臼歯のものより規則的である。エナメル小柱の断面は, 直径 $4 \sim 5 \mu \mathrm{m}$ の鍵穴型でほぼ七 トと同様である。また，臼歯で認められ，Elephas の特徵であるイチョウの葉型のエナメル小柱は観察されな かった。Moeritherium・Palaeomastodon の臼歯のエナメル質では規則的なシュレーゲルの条紋が発達し, エナメル小柱は Mastodon と同様に 鍵穴 型である。

Elephas maximus の牙 (側切歯) のエナメル質は， 臼歯のそれよりも， Moeritherium や Palaeomast- 
odon, Mastodon, Stegodon などの Elephas の先祖の臼歯エナメル質とよく類似した組織学的特徴を示し ている。これは牙と臼歯が著しく異なる方向へ形態的発達をとげた結果を反映しているものと推定できよう。

\section{文献}

1) Boyde, A. : The structure of developing mammalian dental enamel. In Tooth Enamel (ed. by M. V. Stack and R. W. Fearnhead.), pp 163-167. John wright and Sons Ltd., Bristal, 1965.

2) Carter, J. T. : On the structure of the enamel in the primates and some other mammals. Proc. Zool. Soc. Londan, 599-608, Figs. 111, 1922.

3) Driak, F. : Anatomical and histological examination of the structure and development of the elephant molar. J. Dent. Res. 16: 73 $-80,1937$.

4) 井尻正二, 川井尚文 : 長鼻類の歯の組織につい て, 東京科学博物館研究報告。23: 1-6, 図1-5, 1948.

5) 井尻正二, 菅沼音一, 川井尚文：インド象 Elephas maximus) の頭部の解剖図説一特に歯亯 骨 (Os sacculi dentis) を中心にして一, 東京科 学博物館研究報告, $24: 1-7$. 図1-9, 附図1-4, 1949.

6）亀井節夫：象のきた道. 中央公論社, 東京. 1979.

7) Kawai, N. : Comparative anatomy of the ba- nds of Schreger. Okajimas Folia Anat. Jap. . 27 : 115-131, P1. 1-7, 1955.

8）小沢幸重 : 長鼻類の歯の組織学, 口病誌 45 : 585-606, 1978.

9) 小沢幸重 : アジアゾウ (Elephas maximus) の 切歯(牙)の組織学的研究, エナメル質とセメン 卜質について, 地球科学 $36: 231-239,1982$.

10) Maglio, V. J. : Origin and evolution of the Elephantidae. Trans. Amer. Phil. Soc., (new ser. ). $63: 1-126,1973$.

11) Miller, W. D. : Studies on the anatomy and pathology of the tusk of the elephant. Dental Cosmos, $32: 337-357,421-429,1890$.

12) Mummery, J. H. : On the structure and arrangement of the enamel prisms, especially as shown in the enamel of elephant. J. Dent. Sci. 59 : 529-542, 1916.

13) Osborn, H. : Proboscidea, Vol. I, II, Amer. Mus. Nat. Hist., New York, 1936-1942.

14) Shobusawa, M. : Vergleichende Untersuchungen uber die Form der Schmelzprismen der Saugetiere. Okajimas Folia Anat. Jap. 24 : 371-392, P1. I-V. 1952.

15) Sikes, S. K. : The Natural history of the African Elephant. 72-112, Weidenfeld and Nicolson, London, 1971. 


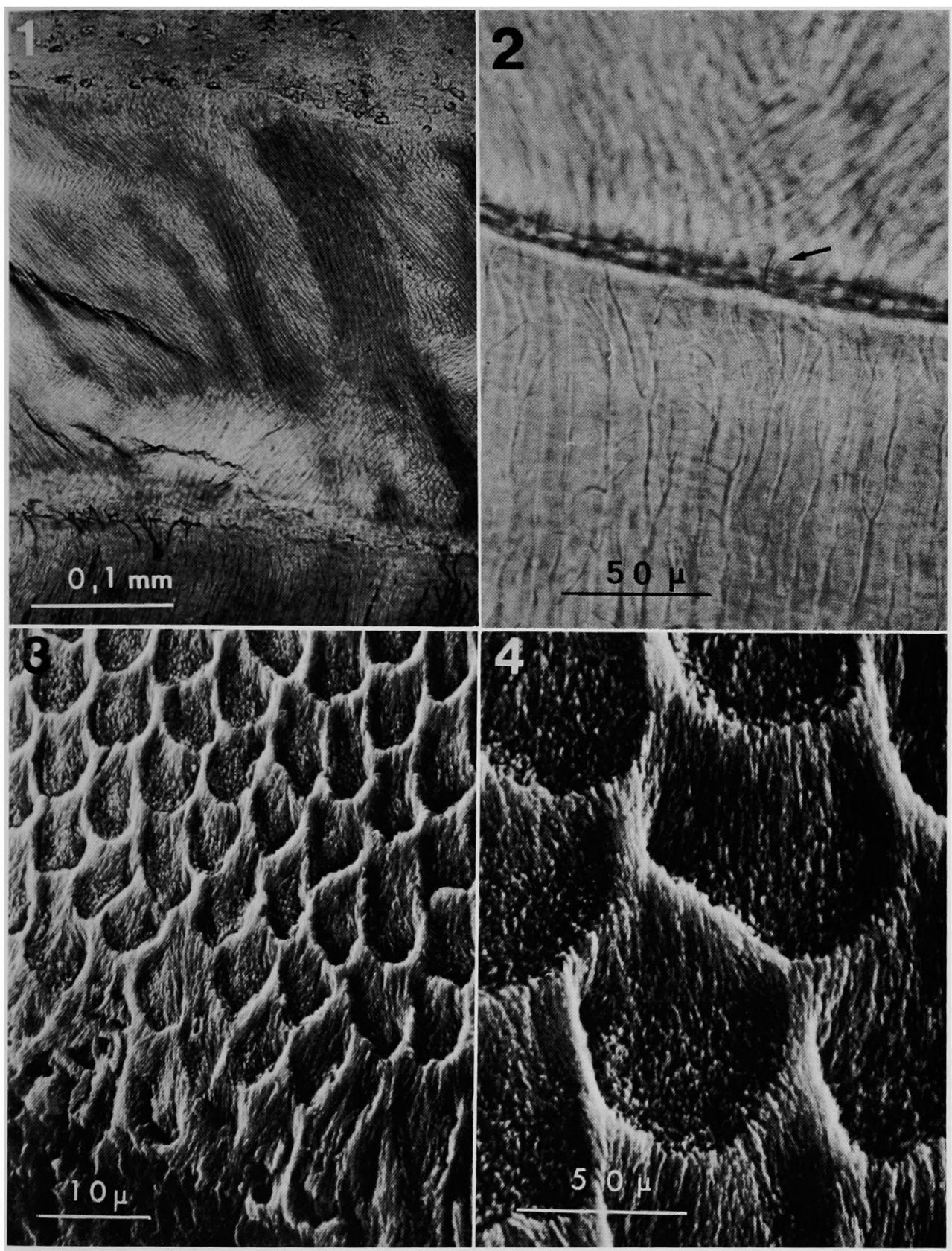

Fig. 1 Enamel of Indian elephant tusk.

Fig. 2 Dentino-enamel junction of Indian elephan tusk. Enamel spindle (arrow) is observed.

Fig. 3 Inner layer of enamel, Indian elephant tusk. The prismless enamel is not observed in the inner enamel layer.

Fig. 4 Enamel prism of Indian elephant tusk forms the key-hole pattern. Interprismatic enamel corresponds to the "tale" of enamel prism. 


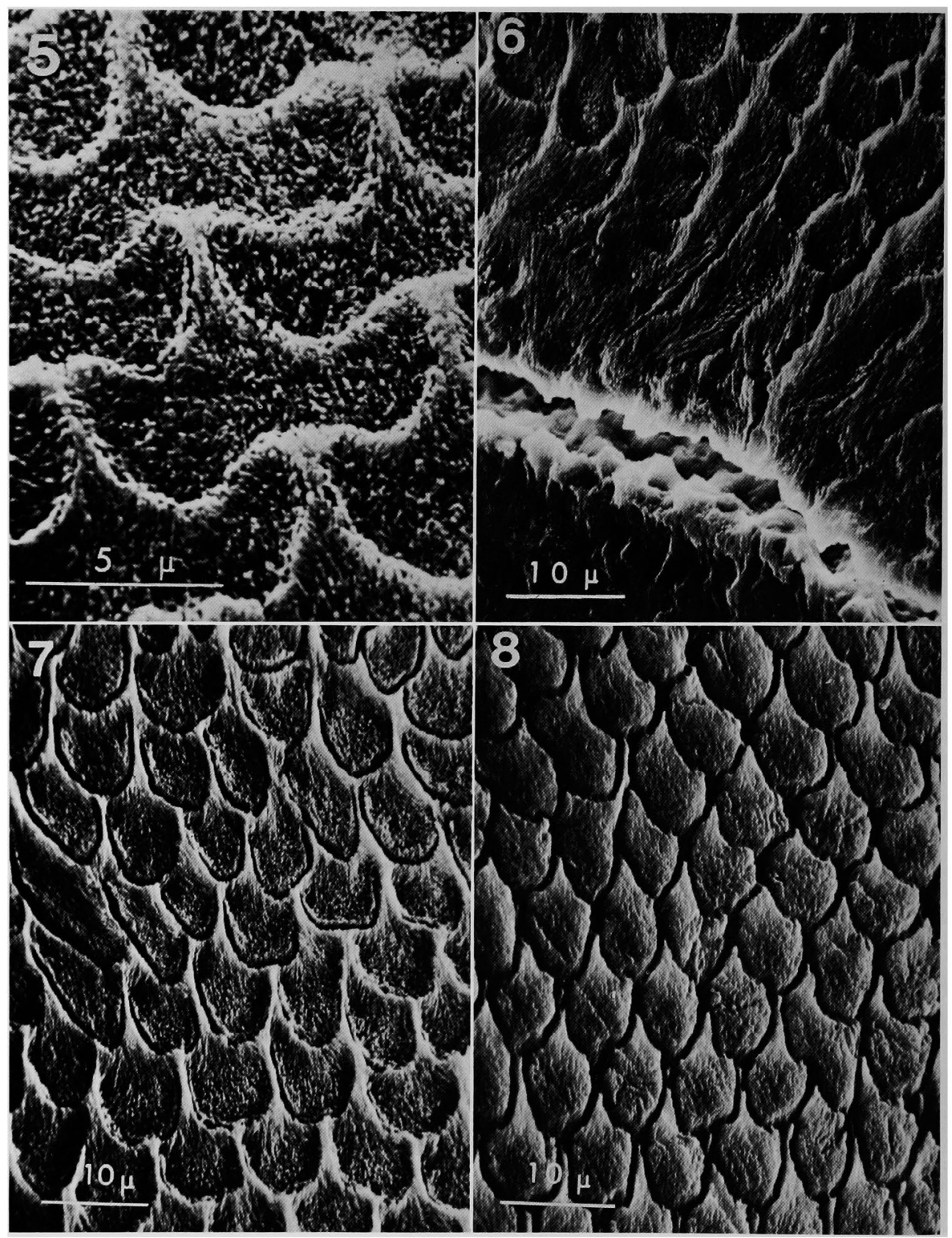

Fig. 5 Enamel prism of Nauman elephant molar. The prism forms the ginkgo-leaf pattern.

Fig. 6 Inner layer of enamel, Indian elephant tusk. The thin prismless enamel is observed at the dentino-enamel junction.

Fig. 7 Outer layer of enamel, Indian elephant tusk. The groove of enamel prism gradually increases to the outer layer.

Fig. 8 Outer layer of enamel, Indian elephant tusk. The enamel prism pattern is unclear. The arrangement of enamel crystal is not distinct. 


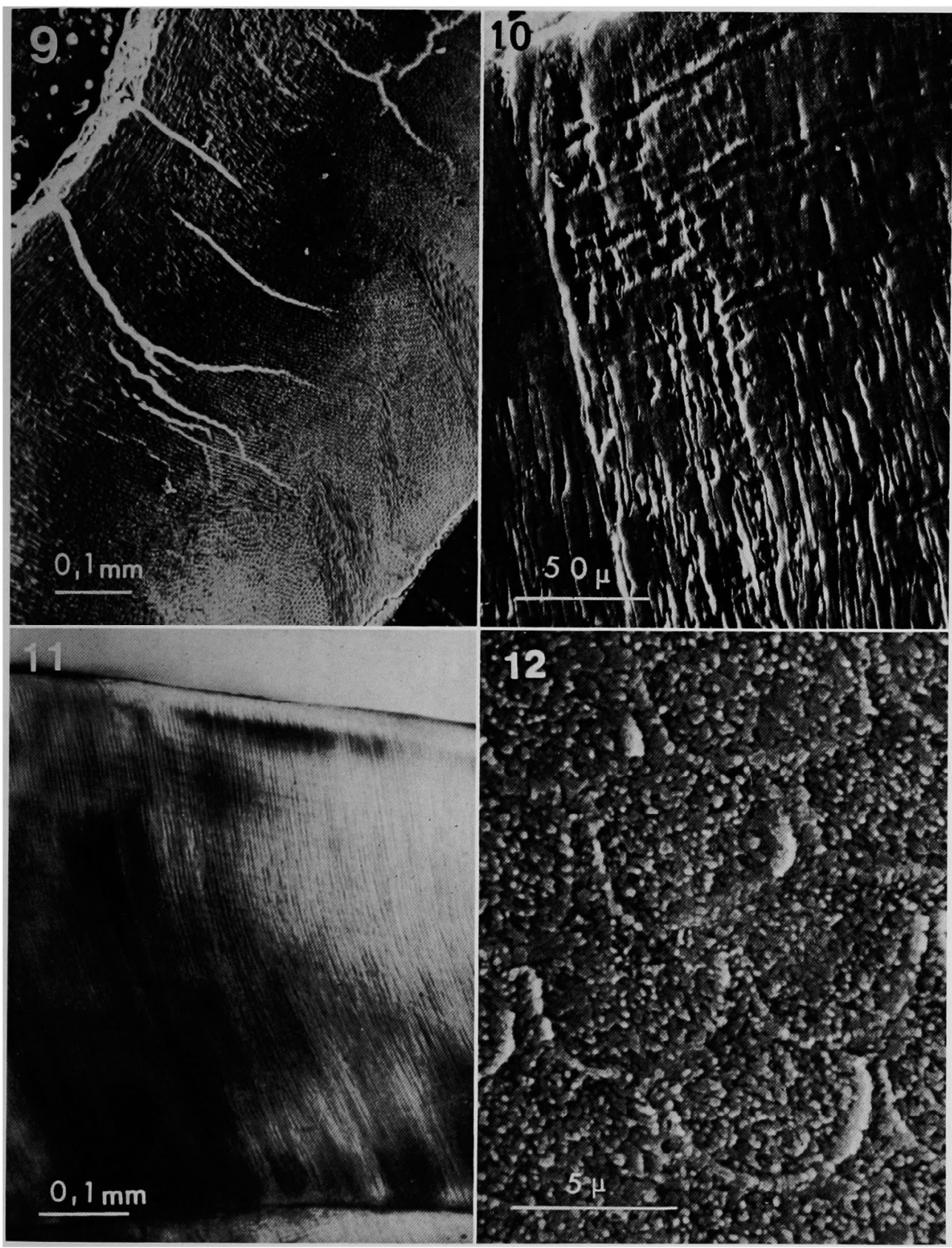

Fig. 9 Enamel of Indian elephant tusk. The outer one-third is a prismless enamel layer with distnct Retziuslines.

Fig. 10 Superficial layer of enamel, Indian elephant.

Fig. 11 Enamel of Moeritherium. The enamel prism runs slightly curved from the inner to the outer surface.

Fig. 12 Enamel prism of Moeritherium. Theenamel prism forms the key-hole pattern. 

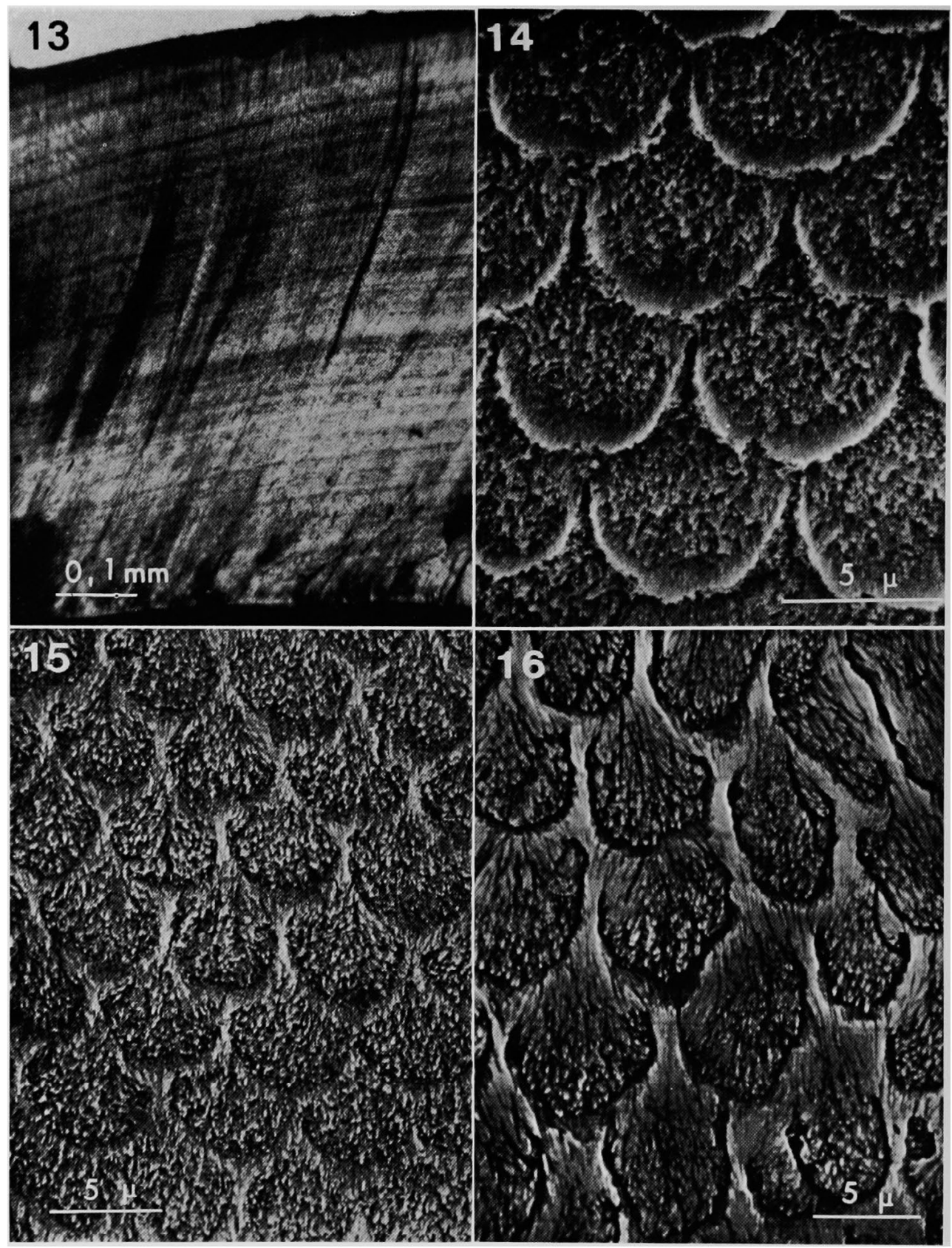

Fig. 13 Enamel of Palaeomastodon. Hunter-Schreger bands are visible.

Fig. 14 Enamel prism of Palaeomastodon. The prism forms the key-hole pattern same as that of Moeritherium.

Fig. 15 Enamel prism of Mastodon molar. The prism forms the key-hole pattern same as that of Moeritheriun and Palaeomastodon.

Fig. 16 Enamel prism of Stegodon molar. The prism pattern is similar to the Mastodon enamel. 